\title{
Day/Night Temperature Affects Growth and Photosynthesis of Cultivated Salvia Taxa
}

\author{
F. Todd Lasseigne ${ }^{1}$, Stuart L. Warren ${ }^{2,5}$, Frank A. Blazich ${ }^{3}$, and Thomas G. Ranney ${ }^{4}$ \\ Department of Horticultural Science, North Carolina State University, Raleigh, NC 27695-7609
}

\begin{abstract}
Additional IndEX wORDs. scarlet sage, heat tolerance, high temperature stress, herbaceous perennials, Lamiaceae
Abstract. Eight taxa of Salvia L., representing broad geographic origin and diversity within the genus, were grown under long day conditions for $36 \mathrm{~d}$ at 15 -h days of $20,25,30,35$, or $40{ }^{\circ} \mathrm{C}$ and 9-h nights of 15 or $25^{\circ} \mathrm{C}$. Taxa of European origin displayed broader tolerance to high day temperatures (DTs) with the lowest relative reduction in growth and net photosynthesis $\left(\mathrm{P}_{n}\right)$ occurring at DTs $30^{\circ} \mathrm{C}$ or greater compared with those native to North and South America. Salvia splendens Sell. ex Roem. \& Schult. (scarlet sage) was particularly intolerant of high temperatures with all plants dying at days of $40^{\circ} \mathrm{C}$. All plants of $S$. nemorosa $\mathrm{L}$. 'Ostfriesland' ('Ostfriesland' wood sage), S. pratensis L. (meadow sage), and $S$. $\times$ sylvestris $L$. 'Mainacht' ('May Night' salvia) survived at days of $40^{\circ} \mathrm{C}$ with no visual signs of injury, whereas all other taxa except $S$. splendens exhibited stunted, contorted growth with foliar chlorosis and necrosis at $40^{\circ} \mathrm{C}$. Day temperature exerted the primary effect on top growth, root growth, and $P_{n}$ of all taxa. Night temperature effects were significant for some taxa but were of less importance than day temperature.
\end{abstract}

Salvia (salvia) comprises one of the largest genera of flowering plants in the world with 900 to 950 species occurring worldwide except in Australia (Clebsch, 1997; Sytsma and Walker, 2003). As ornamental garden plants, salvias enjoy great popularity with a large number of species, hybrids, and cultivars being represented in cultivation (Armitage, 1997; Lord, 2002; Sutton, 1999). Mexican species have long been prized for their large, showy flowers ranging in color from bright reds and oranges to cobalt blues and rich purples (Compton, 1994; Matschat, 1935). The European salvias, best known from $S$. officinalis L. (common sage), the sage of culinary and herbal uses, also offer several striking ornamental species (Dweck, 2000; Sutton, 1999). Currently, the most widely grown salvia is $S$. splendens, a tender perennial species planted as an annual bedding plant (Armitage, 1997; Sutton, 1999).

Despite both the natural and garden diversity of Salvia taxa, limited information exists on their physiological and environmental tolerances. Beyond the extensive work conducted on S. splendens, little research has been conducted on other cultivated salvias (Arnold, 1998; Latimer et al., 1999; Panagiotopoulos et al., 2000; van Iersel, 1997; Wilson et al., 2003).

High temperatures can limit plant survival and growth in warm-temperate climates such as that of the southeastern

Received for publication 15 Nov. 2007. Accepted for publication 6 Apr. 2007. This research was funded in part by the North Carolina Agricultural Research Service (NCARS), Raleigh, NC.

Use of trade names in this publication does not imply endorsement by the NCARS of products named nor criticism of similar ones not mentioned.

Appreciation is extended to William M. Reece, Juan R. Acedo, and the staff of the Southeastern Plant Environment Laboratory (NC State Univ. Phytotron) for technical assistance and William H. Swallow for statistical assistance.

From a thesis submitted by F.T.L. in partial fulfillment of the requirements for the $\mathrm{PhD}$ degree.

${ }^{1}$ Former Graduate Assistant. Currently Director, Paul J. Ciener Botanical Garden, P.O. Box 1069, Kernersville, NC 27285.

${ }^{2}$ Alumni Distinguished Undergraduate Professor.

${ }^{3}$ Alumni Distinguished Graduate Professor.

${ }^{4}$ Professor, Department of Horticultural Science, North Carolina State University, Mountain Horticultural Crops Research and Extension Center, Fletcher, NC.

${ }^{5}$ Corresponding author. E-mail: stu_warren@ncsu.edu.
United States (American Horticultural Society, 1997). Landscape plants, in particular, are subjected to extreme conditions in urban environments (Harris et al., 1999). Surprisingly, for many plant groups, including Salvia taxa, tolerance to high temperatures remains largely unstudied. Variations in heat tolerance among plants can be resolved by comparing temperature sensitivity of growth, basic physiological processes such as photosynthesis, and survival across a range of temperatures (Burke, 1990, 1995; Hopkins, 1999; Lambers et al., 1998; Larcher, 1994; Leegood, 1995). The potential for acclimation and tolerance to high temperatures is variable among and within species and often reflects the temperature regime of a species' native habitat (Björkman et al., 1980). Photosynthesis is one of the most heat-sensitive processes influencing plant growth (Björkman et al., 1980). The optimal temperature for photosynthesis is often correlated with the optimal temperature for plant growth, and both optima are typically reflective of the plant's native (evolutionary origin) climate (Berry and Björkman, 1980; Ranney et al., 1995). Variation in thermotolerance of photosynthesis and respiratory systems can be principle factors in differentiating growth under high temperatures.

Despite the many studies that have tested short-term, or acute, responses to very high temperatures (e.g., 45 to $55^{\circ} \mathrm{C}$ ), plant productivity is known to be impaired by chronic, or longterm, exposures to lower temperatures (e.g., 30 to $40{ }^{\circ} \mathrm{C}$ ) (Fitter and Hay, 2002). Therefore, the objective of this research was to characterize differences in growth and photosynthetic response to supraoptimal day and night temperatures across a diverse taxonomic range of Salvia.

\section{Materials and Methods}

Eight Salvia taxa were selected to represent a cross-section of growth forms, geographic or cultivated origin, and expected physiological tolerances (Table 1). Plants were derived from the following sources: NEM and SYL-North Creek Nurseries (Landenberg, PA); CHA, GRE, GUA, and LEU-Richard Dufresne (Greensboro, NC); PRA—Chiltern Seeds (Ulverston, UK); and SPL - Buchanan's Nursery (Raleigh, NC). All plants were grown from rooted stem cuttings, except for PRA and 


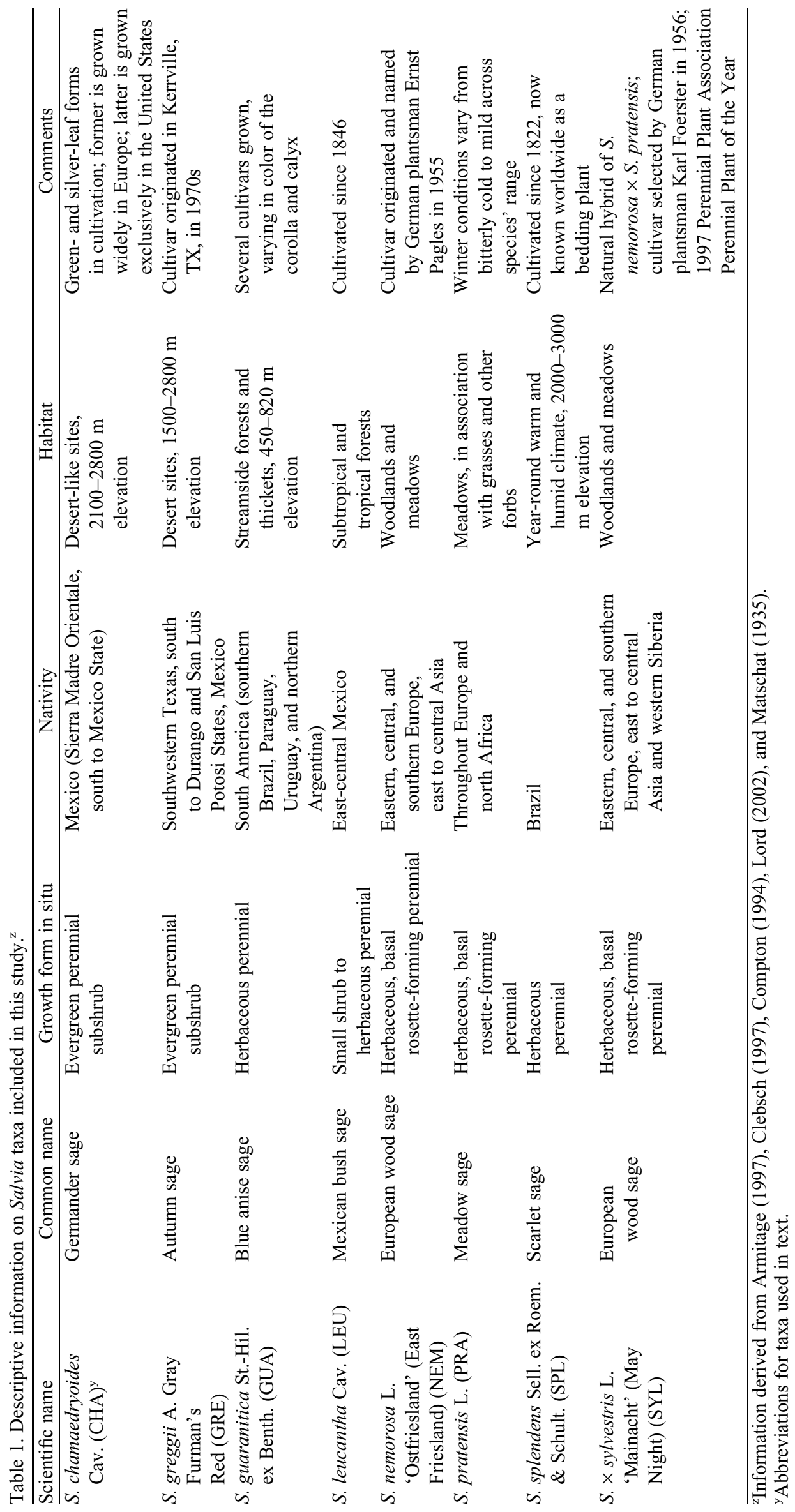


SPL, which were grown from seed. Plants, at 30 to $40 \mathrm{~d}$ old (measured from time of inserting cuttings into rooting medium or from sowing seeds), were transplanted into 3-L black plastic containers (height, $18.5 \mathrm{~cm}$; diameter, $17 \mathrm{~cm}$ ) containing a substrate of 8 pine bark:1 sand (by vol.) amended with 1.8 $\mathrm{kg} \cdot \mathrm{m}^{-3}$ dolomitic limestone. At potting, 10 plants of each taxa were harvested to determine initial top and root dry weights. Plants were dried at $65{ }^{\circ} \mathrm{C}$ until plant weight remained unchanged ( $72 \mathrm{~h}$ ). Initial top and root dry weights, respectively, for each taxa were: $\mathrm{CHA}=0.35 \mathrm{~g}$ and $0.1 \mathrm{~g}, \mathrm{NEM}=0.55 \mathrm{~g}$ and $0.49 \mathrm{~g}, \mathrm{GRE}=1.54 \mathrm{~g}$ and $0.66 \mathrm{~g}, \mathrm{GUA}=0.92 \mathrm{~g}$ and $0.69 \mathrm{~g}, \mathrm{LEU}=$ $1.42 \mathrm{~g}$ and $1.0 \mathrm{~g}, \mathrm{SYL}=0.62 \mathrm{~g}$ and $0.83 \mathrm{~g}, \mathrm{PRA}=1.10 \mathrm{~g}$ and $0.74 \mathrm{~g}$, and $\mathrm{SPL}=0.87 \mathrm{~g}$ and $1.54 \mathrm{~g}$.

On 29 Sept. 1997, all plants of the eight taxa were transferred to one of five B chambers at the Southeastern Plant Environment Laboratory (North Carolina State University Phytotron) (Thomas et al., 2004). For $7 \mathrm{~d}$, all plants were grown under a 15-h day/9-h night thermoperiod of $25 / 20{ }^{\circ} \mathrm{C}$ with a 15 -h photoperiod. From 0800 to 2300 HR daily, chamber irradiance was provided by a combination of cool-white fluorescent lamps and incandescent bulbs providing a photosynthetic photon flux of $642 \mu \mathrm{mol} \cdot \mathrm{m}^{-2} \cdot \mathrm{s}^{-1}$. Plants were watered and fertilized in the morning on alternating days with a complete nutrient solution (including micronutrients) providing $\mathrm{N}, \mathrm{P}$, and $\mathrm{K}$ at 106,10 , and $111 \mathrm{mg} \cdot \mathrm{L}^{-1}$, respectively (Thomas et al., 2004). All plants were checked in the afternoon to determine if additional water was needed to maintain adequate substrate moisture.

On 6 Oct. 1997 (day 1), plants were arranged as a $5 \times 2 \times 8$ factorial in a randomized complete block design with eight single-plant replications. The three main factors were 5 -d temperatures [DTs $\left(20,25,30,35\right.$, or $\left.40{ }^{\circ} \mathrm{C}\right)$ ], two night temperatures [NTs $\left(15\right.$ or $\left.25^{\circ} \mathrm{C}\right)$ ], provided to plants as $15-\mathrm{h}$ day/9-h night thermoperiods, and eight salvia taxa. The $15{ }^{\circ} \mathrm{C}$ nights were representative of a "cool" night temperature, whereas $25^{\circ} \mathrm{C}$ was considered representative of "warm" nights based on summer conditions in Raleigh, NC. Temperatures were maintained within $\pm 0.25{ }^{\circ} \mathrm{C}$ of the set point. Plants were moved between chambers at 0800 and 2300 HR daily to maintain appropriate day/night temperatures. Plants exposed to the same day and night temperatures were also moved daily to different areas of the chamber to simulate transient mechanical perturbations. Relative humidity $(\mathrm{RH})$ was greater than $70 \%$, and $\mathrm{CO}_{2}$ concentration averaged $350 \mu \mathrm{mol} \cdot \mathrm{m}^{-3}$.

On days 23 to 25 , leaf gas exchange was measured with a portable infrared gas exchange system (LI-COR 6200; LI-COR, Lincoln, NE). Photosynthetically active radiation, air and leaf temperatures, and RH inside a $0.25-\mathrm{L}$ leaf chamber were measured concurrently with gas exchange for $30 \mathrm{~s}$. Data were recorded from a recently matured leaf or leaves depending on taxa on each of four plants per taxa at DTs of 20,30 , or $40^{\circ} \mathrm{C}$ at both NTs. Net leaf photosynthetic $\left(\mathrm{P}_{\mathrm{n}}\right)$ rates and $g_{\mathrm{S}}$ were expressed on a leaf area basis, and leaf areas were determined using a LI-COR 3100 leaf area meter. Leaf internal $\mathrm{CO}_{2}$ concentration $\left(\mathrm{C}_{\mathrm{i}}\right)$ was calculated using the LI-COR 6200 software.

On day 36, plants were divided into leaves, stems, flowers (when present), and roots, and total leaf area was measured with a LI-COR 3100 leaf area meter. Leaf area of GRE was not measured as a result of the presence of glandular-tipped hairs on the leaves that adhered to the leaf area meter. Roots were placed over a screen and washed with a high-pressure water stream to remove substrate. All plant organs were dried at $65{ }^{\circ} \mathrm{C}$ until plant weight remained unchanged $(72 \mathrm{~h})$ and weighed. These data were used to calculate the following: top dry weight (leaf + stem dry weights), root:top ratio [RTR (root dry weight $\div$ top dry weight)], and specific leaf weight [SLW (leaf dry weight $\div$ leaf area)].

Data were analyzed using Proc analysis of variance in SAS (version 8.01; SAS Institute, Cary, NC). All interactions that included Salvia taxa were highly significant $(P \leq 0.01)$ indicating all variables varied according to taxon. Therefore, data were reanalyzed by taxon as a $5 \times 2$ factorial. Simple linear or polynomial curves were fitted to the day temperature data when significant trends were identified in regression analyses. The maximum of the polynomial curve was calculated as a firstorder derivative of the independent variable in which the dependent variable equaled zero. When appropriate, mean separations were performed through Fisher's protected least significance difference (LSD) procedure at $P=0.05$.

\section{Results and Discussion}

Temperature affected top dry weight, stem dry weight, leaf dry weight, and leaf area similarly in all taxa and only top dry weight data are presented. Top dry weight of all Salvia taxa was affected by DT but not by NT (except LEU and SPL) nor the day $\times$ night temperature interaction $(\mathrm{DT} \times \mathrm{NT})$ for all taxa (Table 2).

Top dry weight of all taxa responded quadratically to increasing DT with a calculated maximum top dry weight occurring at $24,30,22,25,29,37,33$, and $26^{\circ} \mathrm{C}$ for CHA, NEM, GRE, GUA, LEU, SYL, PRA, and SPL, respectively $\left(\mathrm{LSD}_{0.05}=2.1\right)($ Fig. $1 \mathrm{~A}, \mathrm{~B})$. This is the classic response to temperature with growth increasing with increasing temperature until an optimum is reached above which growth is reduced (McMichael and Burke, 1998). However, the optimal temperatures were very diverse. The three rosette-forming taxa (NEM, SYL, and PRA) exhibited the greatest tolerance to high DTs with maximum growth occurring at DTs $30^{\circ} \mathrm{C}$ or greater. SYL demonstrated remarkable heat tolerance with only a minimal decline $(0.7 \%)$ when comparing plants grown at $40{ }^{\circ} \mathrm{C}$ versus those at $35^{\circ} \mathrm{C}$. In contrast to Salvia originating from Europe (NEM, SYL, and PRA), top dry weight in New World taxa (CHA, GRE, GUA, LEU, and SPL) exhibited maximum growth at DTs $29^{\circ} \mathrm{C}$ or less. Greatest top dry weights occurred at DT $25^{\circ} \mathrm{C}$ or less for CHA, GRE, GUA, and DT of $26^{\circ} \mathrm{C}$ for SPL. In addition, top dry weight of CHA, GRE, GUA, LEU, and SPL declined $77 \%, 64 \%, 69 \%, 69 \%$, and $60 \%$ from 30 to $40{ }^{\circ} \mathrm{C}$ $\left(35^{\circ} \mathrm{C}\right.$ for SPL), respectively. In SPL, no plants survived DTs of $40^{\circ} \mathrm{C}$. All five New World taxa exhibited stunted, contorted growth with foliar chlorosis, and necrosis at $40^{\circ} \mathrm{C}$ (or $35^{\circ} \mathrm{C}$ for SPL) (personal observations). The tolerance of European taxa (NEM, SYL, and PRA) to high DTs was as surprising as the lack of tolerance to high DTs of New World taxa (CHA, GRE, GUA, LEU, and SPL). In particular, SPL, which is used so commonly as a bedding plant both in Europe and North America, responded poorly to high DTs for all factors measured. Our findings with SPL agree with those of Higuchi et al. (1987) who observed strongly retarded growth in plants of S. splendens 'St. John's Fire' exposed to high temperatures (reaching a maximum of $45^{\circ} \mathrm{C}$ ) for 1 week.

For top dry weight, only LEU and SPL were significantly affected by NT (Table 2). Top dry weight of LEU increased $8 \%$ at $25^{\circ} \mathrm{C}$ versus $15^{\circ} \mathrm{C}$, whereas top dry weight of SPL decreased 
Table 2. Statistical significance of top and root dry weights, root:top dry weight ratio, flower dry weight, and specific leaf weight of eight Salvia taxa grown under contrasting day/night temperatures.

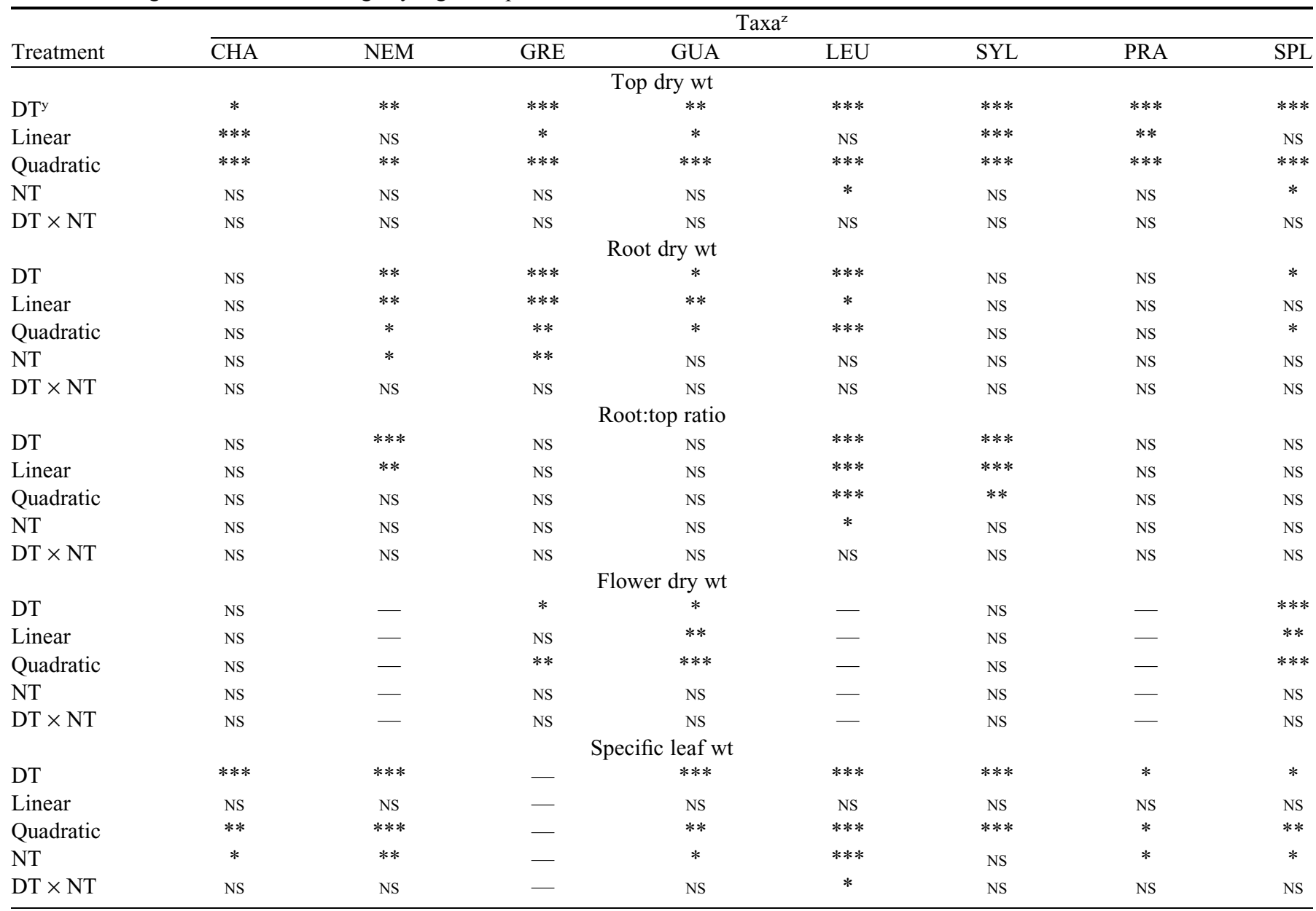

${ }^{\mathrm{z}}$ CHA, NEM, GRE, GUA, LEU, SYL, PRA, and SPL represent Salvia chamaedryoides, $S$. nemorosa Ostfriesland, S. greggii Furman's Red, $S$. guaranitica, $S$. leucantha, $S$. $\times$ sylvestris Mainacht, $S$. pratensis, and $S$. splendens, respectively.

${ }^{\mathrm{y}} \mathrm{DT}, \mathrm{NT}$, and DT $\times$ NT represent day temperature (DT) and night temperature $(\mathrm{NT})$ main effects, and the DT $\times$ NT interaction, respectively. ${ }_{\mathrm{Ns}, * * *, * * *}$ Nonsignificant or significant at $P \leq 0.05,0.01$, or 0.001 , respectively.

$16 \%$ at nights of $25{ }^{\circ} \mathrm{C}$ versus nights of $15{ }^{\circ} \mathrm{C}$ (data not presented). This latter decrease may have been the result of increased dark respiration (not measured in this study) with increasing NT (Jiao and Grodzinski, 1996; Lambers et al., 1998; Leegood, 1995). Increased dry weight with increasing NT was unexpected but may relate to inherent physiological adaptations based on the native climate of the species' geographical range, resulting in a species with less physiological plasticity as observed in cultivation outside its native climatic range. (LEU, as the only taxon studied that is native to subtropical and tropical climates at low altitudes, may exhibit sensitivity to low NTs.) Contrasting results have also been found in other genera. Flowering of Primula $\times$ polyanthus Mill. (polyantha primrose) 'Pacific Giant Dwarf Jewel Strain' was unaffected by NT ( 10 versus $20^{\circ} \mathrm{C}$ ) (Armitage and Billingsley, 1983), whereas optimum flowering of $P$. vulgaris Huds. (primrose) 'Dania Lemon Yellow' occurred at $13{ }^{\circ} \mathrm{C}$ (constant day/night temperatures) (Karlsson, 2002). This demonstrates a within-genus difference for Primula L. mirroring that seen for Salvia herein.

Root dry weight of all taxa was unaffected by DT $\times$ NT interaction (Table 2).
In contrast to top dry weight in which all taxa increased quadratically to increasing DT (Fig. 1), root dry weight responded linearly, quadratically, or was unaffected by DT depending on the taxa (Table 2). Root dry weight of NEM, GRE, and GUA declined linearly with increasing DT indicating optimal DT for root growth was $20^{\circ} \mathrm{C}$ or less (Fig. 2), whereas optimal DT for top dry weight was 30,22 , and $25{ }^{\circ} \mathrm{C}$, respectively (Fig. 1). Other studies have reported optimal DT for root growth was lower than for top growth (Jull et al., 1999; Malek et al., 1992; Rowe et al., 1994). Root dry weight of LEU and SPL increased quadratically with increasing DT with calculated maximum dry weight at DTs of $27{ }^{\circ} \mathrm{C}$ and $26{ }^{\circ} \mathrm{C}$, respectively (Fig. 2), which was similar to optimal DTs for top dry weight of $29^{\circ} \mathrm{C}$ and $26^{\circ} \mathrm{C}$, respectively (Fig. 1). Root dry weight of CHA, SYL, and PRA was unaffected by DT (data not presented). This may reflect the apparent tolerance to high DTs of SYL and PRA as exemplified by top dry weight. Only root dry weight of NEM and GRE was affected by NT decreasing $18 \%$ and $33 \%$, respectively, at nights of $25^{\circ} \mathrm{C}$ versus nights of $15{ }^{\circ} \mathrm{C}$ (Table 2, data not presented). Presumably, higher NT resulted in greater loss of respiratory carbohydrates, which reduced dry weight accumulation because temperature is the 

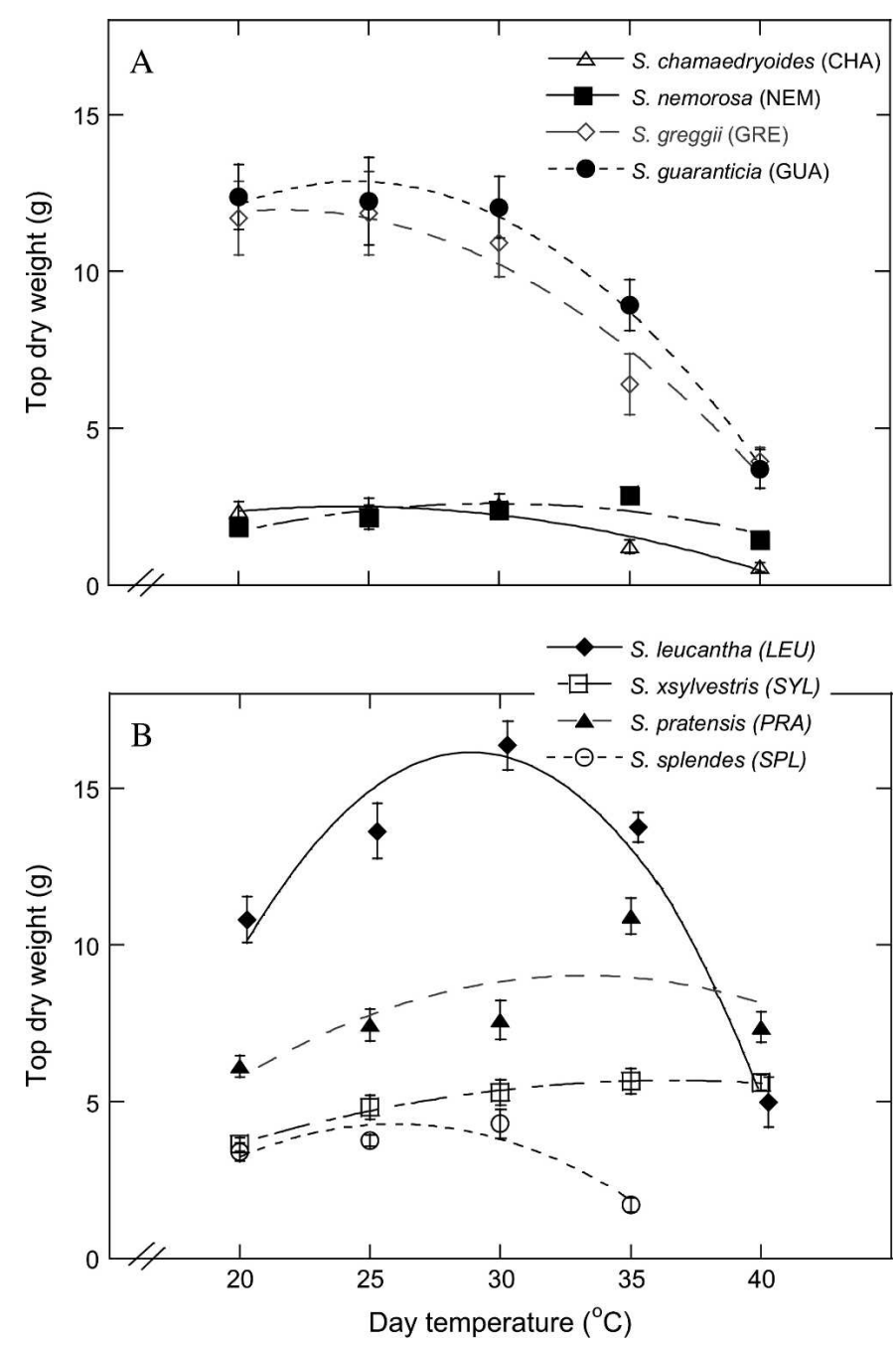

Fig. 1. Effects of day temperature on top dry weight of eight Salvia taxa. Symbols are means of 16 observations, vertical bars are $\pm 1 \mathrm{SE}$, and curves show significant quadratic effects. (A) S. chamaedryoides [CHA (top dry weight $=$ $\left.-2.2+0.39 \mathrm{x}-0.008 \mathrm{x}^{2}, R^{2}=0.92\right)$ ], $S$. nemorosa 'Ostfriesland' [NEM (top dry weight $\left.=-5.6+0.55 \mathrm{x}-0.009 \mathrm{x}^{2}, R^{2}=0.64\right)$ ], S. greggii 'Furman's Red' [GRE (top dry weight $\left.\left.=0.15+1.09 \mathrm{x}-0.025 \mathrm{x}^{2}, R^{2}=0.96\right)\right]$, and $S$. guaranitica [GUA (top dry weight $\left.\left.=-9.58+1.83 \mathrm{x}-0.038 \mathrm{x}^{2}, R^{2}=0.99\right)\right]$; $($ B) $S$. leucantha [LEU (top dry weight $\left.\left.=-50.5+4.66 \mathrm{x}-0.081 \mathrm{x}^{2}, R^{2}=0.95\right)\right], S . \times$ sylvestris 'Mainacht' [SYL (top dry weight $=-4.01+0.53 \mathrm{x}-0.007 \mathrm{x}^{2}, R^{2}=0.99$ )], S. pratensis [PRA (top dry weight $=-11.5+1.24 \mathrm{x}-0.019 \mathrm{x}^{2}, R^{2}=0.52$ )], and $S$. splendens $\left[\mathrm{SPL}\right.$ (top dry weight $=-15.6+1.53 \mathrm{x}-0.030 \mathrm{x}^{2}, R^{2}=0.86$ )].

most important environmental factor influencing dark respiration (Levitt, 1980).

Top and root dry weight of LEU were inhibited by both low and high DTs with a sharp decrease $(69 \%$ and $76 \%$, respectively) from 30 to $40{ }^{\circ} \mathrm{C}$. Although days of $20{ }^{\circ} \mathrm{C}$ are not normally considered suboptimal for most plants, LEU showed a definite spike in growth as DTs increased from 20 to $30{ }^{\circ} \mathrm{C}$, decreasing markedly both below and above the cardinal values. Growth inhibition of LEU at low DTs may relate to suboptimal temperature conditions for adequate growth as has been reported for $S$. splendens 'Carabiniere' and 'Johannisfeuer' grown at 10 or $14{ }^{\circ} \mathrm{C}$ (Zimmer, 1980) and 'America' grown at $10^{\circ} \mathrm{C}$ (Cooper and Watson, 1954). LEU was the only taxon studied native to subtropical and tropical climates at low altitudes. Thus, it may exhibit

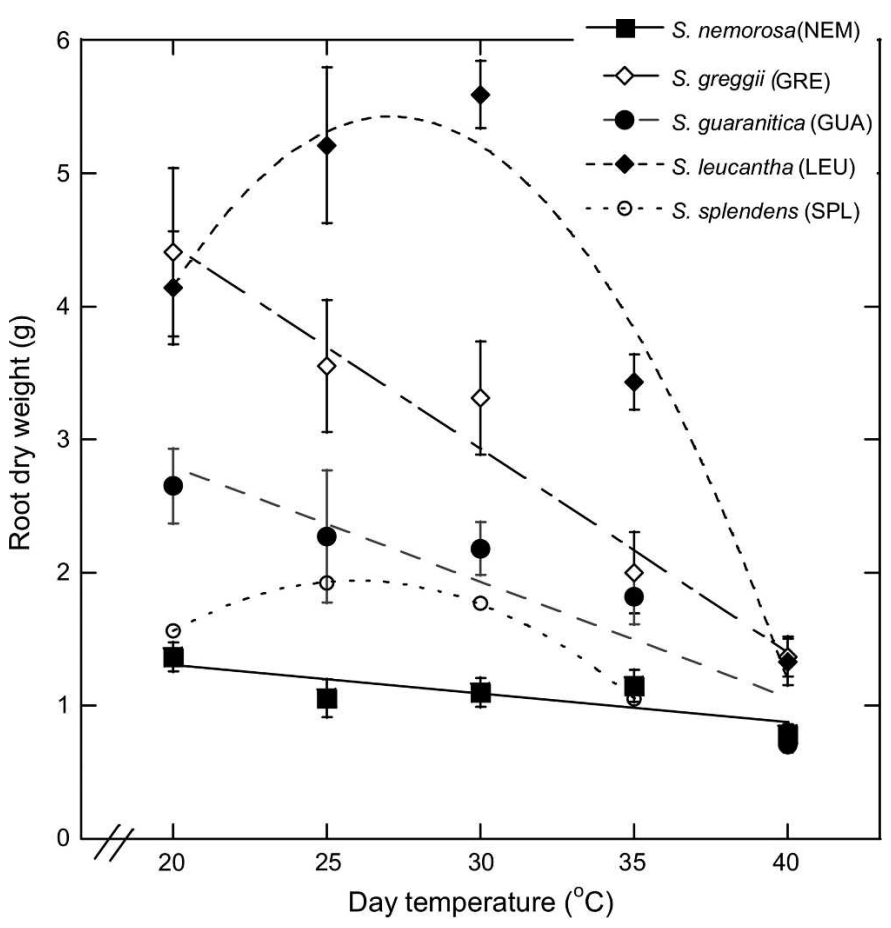

Fig. 2. Effects of day temperature on root dry weight of five Salvia taxa. Symbols are means of 16 observations, vertical bars are $\pm 1 \mathrm{SE}$, and curves show significant linear or quadratic effects. S. nemorosa 'Ostfriesland' [NEM (root dry weight $\left.\left.=1.74+0.02 \mathrm{x}, R^{2}=0.66\right)\right], S$. greggii 'Furman's Red' [GRE (root dry weight $=7.51+0.15 \mathrm{x}, R^{2}=0.97$ )], $S$. guaranitica [GUA (root dry weight $\left.\left.=4.52+0.87 \mathrm{x}, R^{2}=0.85\right)\right], S$. leucantha $[\mathrm{LEU}$ (root dry weight $=$ $\left.\left.-13.19+1.37 \mathrm{x}-0.025 \mathrm{x}^{2}, R^{2}=0.97\right)\right]$, and S. splendens [SPL (root dry weight $\left.\left.=-5.29+1.37 \mathrm{x}-0.025 \mathrm{x}^{2}, R^{2}=0.97\right)\right]$.

sensitivity to low DTs. In contrast, taxa native to cooler climates (CHA, NEM, GRE, GUA, and SPL) performed well at $20^{\circ} \mathrm{C}$.

Carbon allocation (RTR) was affected by DT within three taxa (Table 2). The RTR of LEU decreased linearly with increasing DT indicating root growth was more temperaturesensitive than top growth (Fig. 3). Likewise, RTR of mountain laurel (Kalmia latifolia L.) and catawba rhododendron (Rhododendron catawbiense Michx.) decreased with increasing DT (Malek et al., 1992; Rowe et al., 1994). RTR of NEM and SYL responded quadratically to increasing DT with a calculated minimum RTR occurring at $32{ }^{\circ} \mathrm{C}$ and $35^{\circ} \mathrm{C}$, respectively (Fig. 3), indicating at DTs $33{ }^{\circ} \mathrm{C}$ or greater or $36^{\circ} \mathrm{C}$ or greater, respectively, top growth decreased more than root growth. Surprisingly, RTR of CHA, GRE, GUA, PRA, and SPL was unaffected by DT, NT, or DT $\times$ NT indicating growth of tops and roots responded similarly to temperature (data not presented). Jull et al. (1999) reported RTR of provenances of atlantic white cedar [Chamaecyparis thyoides (L.) B.S.P.] was affected by increasing DT with responses ranging from linear to quadratic to unaffected. The diversity of results may not be surprising based on Kasper and Bland (1992) who reported a decrease in RTR at both low and high DTs, whereas Cooper (1973) stated the most common response was higher RTR at low and high DTs.

Of the Salvia taxa studied, NEM, LEU, and PRA did not flower, either as a result of photoperiod or possibly lack of maturity or vernalization (Armitage and Laushman, 1989; Clebsch, 1997). Flower dry weight of GRE, GUA, and SPL 


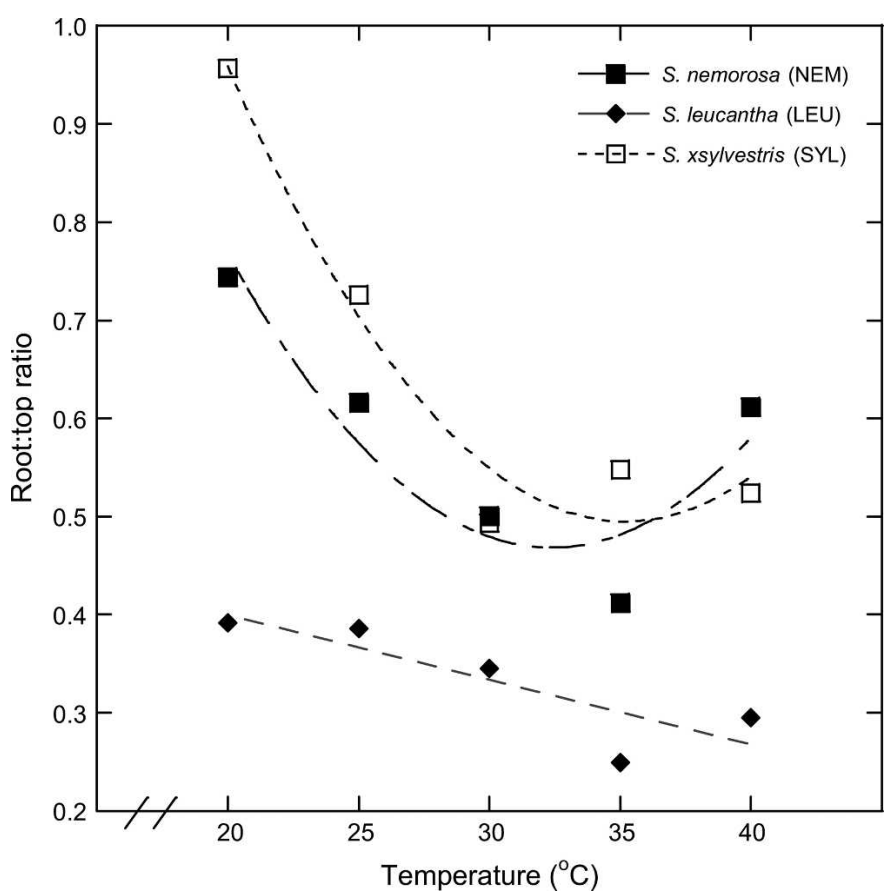

Fig. 3. Effects of day temperature on root:top ratio (RTR) of three Salvia taxa. Symbols are means of 16 observations, vertical bars are \pm 1 SE, and curves show significant linear or quadratic effects. S. nemorosa 'Ostfriesland' [NEM $\left.\left(\mathrm{RTR}=2.50+0.126 \mathrm{x}-0.002 \mathrm{x}^{2}, R^{2}=0.87\right)\right], S$. leucantha $[\mathrm{LEU} *(\mathrm{RTR}=$ $\left.\left.0.53+0.007 \mathrm{x}, R^{2}=0.73\right)\right]$, and $S . \times$ sylvestris 'Mainacht' $[\mathrm{SYL}(\mathrm{RTR}=2.98+$ $\left.\left.0.141 \mathrm{x}-0.002 \mathrm{x}^{2}, R^{2}=0.96\right)\right]$.

increased quadratically with increasing DT with calculated maxima at 25,23 , and $23{ }^{\circ} \mathrm{C}$, respectively (Fig. 4), which were similar to the optimal DTs for top dry weight (Fig. 1). Both GRE and SPL produced flowers that did not develop fully at DTs $35^{\circ} \mathrm{C}$ or greater. Of these three taxa, GUA produced twice as much or more floral biomass than either GRE or SPL $\left(\operatorname{LSD}_{0.05}=\right.$ 0.2). Similar to root dry weight, flower dry weight of GRE, GUA, and SPL was unaffected by NT and DT $\times$ NT interaction (Table 2). Flower dry weight of CHA and SYL was unaffected by DT, NT, and DT $\times$ NT interaction (Table 2, data not presented).

Specific leaf weight is a morphological index that can be used as an indirect measure of leaf thickness with a high ratio generally corresponding to a thick leaf (Friend et al., 1994). Therefore, lower SLW values were regarded as indicative of low strain on plants grown in this experiment.

SLW of all Salvia taxa (excluding GRE in which leaf area was not measured) was significantly affected by DT (Table 2), whereas SLW was also affected by NT more than any other measured parameter. In addition, LEU had a significant DT $\times$ NT interaction. However, although SLW was significantly affected by DT, SLW was fairly stable at DTs of 20, 25, and $30{ }^{\circ} \mathrm{C}$ for New World taxa of CHA and SPL with an abrupt increase in SLW at $35^{\circ} \mathrm{C}$ (Fig. 5). Likewise, SLW of GUA was similar until $40{ }^{\circ} \mathrm{C}$, the inflection point indicating the DT at which plant growth nearly stopped. Similar to GUA, SLW of NEM and LEU were stable at DTs of $20,25,30$, and $35^{\circ} \mathrm{C}$ with SLW increasing abruptly at $40{ }^{\circ} \mathrm{C}$ (data not presented). Old World taxa (SYL and PRA) revealed a nearly steady, although significant, response of SLW to DT that corresponded with the observed, relative tolerance to high DTs in these taxa. LEU

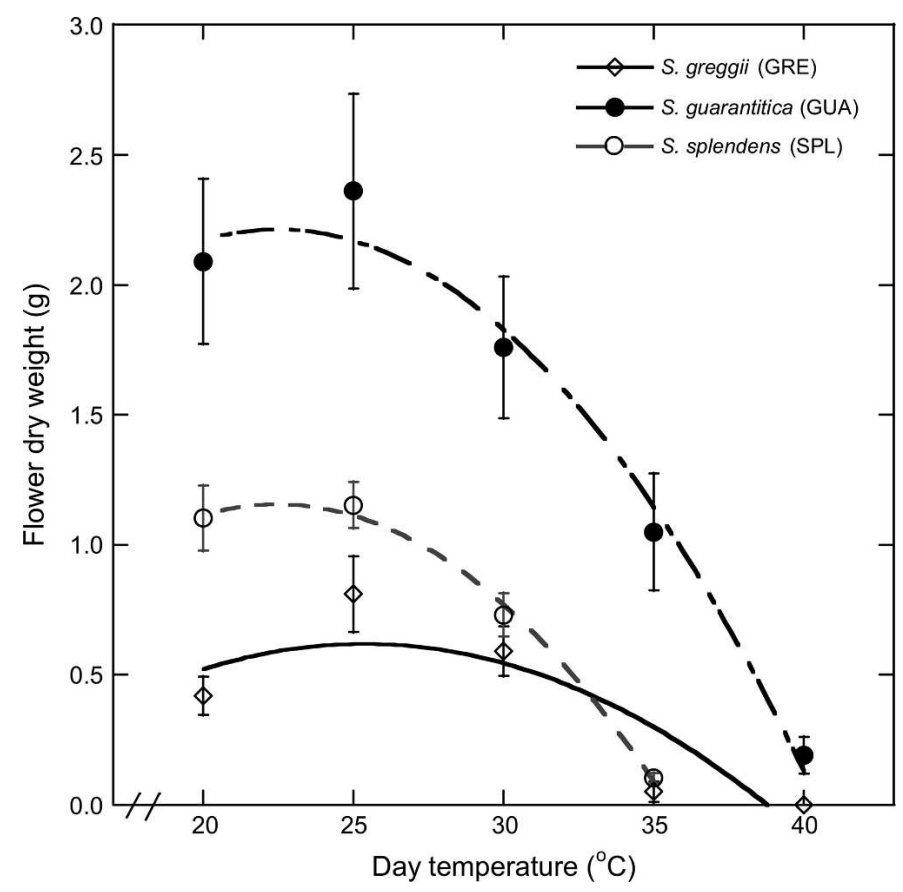

Fig. 4. Effects of day temperature on flower dry weight of three Salvia taxa. Symbols are means of 16 observations, vertical bars are \pm 1 SE, and curves show significant quadratic effects. S. greggii 'Furman's Red' [GRE (flower dry weight $\left.\left.=-1.58+0.174 \mathrm{x}-0.003 \mathrm{x}^{2}, R^{2}=0.74\right)\right], S$. guaranitica [GUA (flower dry weight $\left.\left.=-1.20+0.304 \mathrm{x}-0.007 \mathrm{x}^{2}, R^{2}=0.98\right)\right]$, and $S$. splendens [SPL (flower dry weight $=-2.26+0.304 \mathrm{x}-0.007 \mathrm{x}^{2}, R^{2}=0.99$ )].

showed clear separation of plants grown at nights of 15 or $25^{\circ} \mathrm{C}$ only at days of $40{ }^{\circ} \mathrm{C}$ (data not presented), with $15^{\circ} \mathrm{C}$ nights producing higher SLWs compared with $25^{\circ} \mathrm{C}$ NT, indicating increased leaf thickening and decreased leaf size, which may be another indicator of sensitivity to low NT. In contrast, SLW of NEM, GUA, PRA, and SPL decreased 13\%, 3\%, 10\%, and $18 \%$, respectively, as NT increased from $15{ }^{\circ} \mathrm{C}$ to $25^{\circ} \mathrm{C}$ (data not presented) indicating increased heat strain (thicker, smaller leaves) at higher NT.

$P_{n}$ of all taxa were affected by DT; however, $P_{n}$ was unaffected by NT and DT $\times$ NT (data not presented). The response of $\mathrm{P}_{\mathrm{n}}$ to DT fell into one of four categories. CHA, NEM, and SPL had similar levels of $P_{n}$ at DTs of 20 and $30{ }^{\circ} \mathrm{C}$ with a subsequent decrease at $40{ }^{\circ} \mathrm{C}\left(\mathrm{SPL}\right.$ was dead at $\left.40{ }^{\circ} \mathrm{C}\right), \mathrm{P}_{\mathrm{n}}$ of GRE and LEU decreased with every increase of DT with the highest $\mathrm{P}_{\mathrm{n}}$ at $20^{\circ} \mathrm{C}, \mathrm{P}_{\mathrm{n}}$ of GUA was greatest at a DT of $30^{\circ} \mathrm{C}$ with significant decreases at both 20 and $40{ }^{\circ} \mathrm{C}$, and $P_{n}$ of SYL and PRA were unaffected by DT (Table 3). Jiao and Grodzinski (1996) reported $\mathrm{P}_{\mathrm{n}}$ of $S$. splendors was reduced $55 \%$ and $80 \%$ when a leaf was exposed to 35 and $40{ }^{\circ} \mathrm{C}$ compared with maximum $\mathrm{P}_{\mathrm{n}}$, which was obtained at $25^{\circ} \mathrm{C}$. $\mathrm{P}_{\mathrm{n}}$ of CHA, GRE, and GUA, which had optimal DTs for top dry weight of less than $25^{\circ} \mathrm{C}$, decreased $109 \%, 97 \%$, and $109 \%$ from 30 to $40{ }^{\circ} \mathrm{C}$, respectively, whereas $\mathrm{P}_{\mathrm{n}}$ of NEM, LEU, SYL, and PRA, which had optimal DTs greater than $29{ }^{\circ} \mathrm{C}$, declined $27 \%, 24 \%, 5 \%$, and $16 \%$ from 30 to $40{ }^{\circ} \mathrm{C}$, respectively. This is markedly similar to the top dry weight response to DT presented previously (Fig. 1). Because almost all dry weight accumulation of plants is the result of carbon fixation, $\mathrm{P}_{\mathrm{n}}$ might be expected to be correlated with plant growth. However, $\mathrm{P}_{\mathrm{n}}$ is not always well correlated with growth (van Iersel, 2003). 


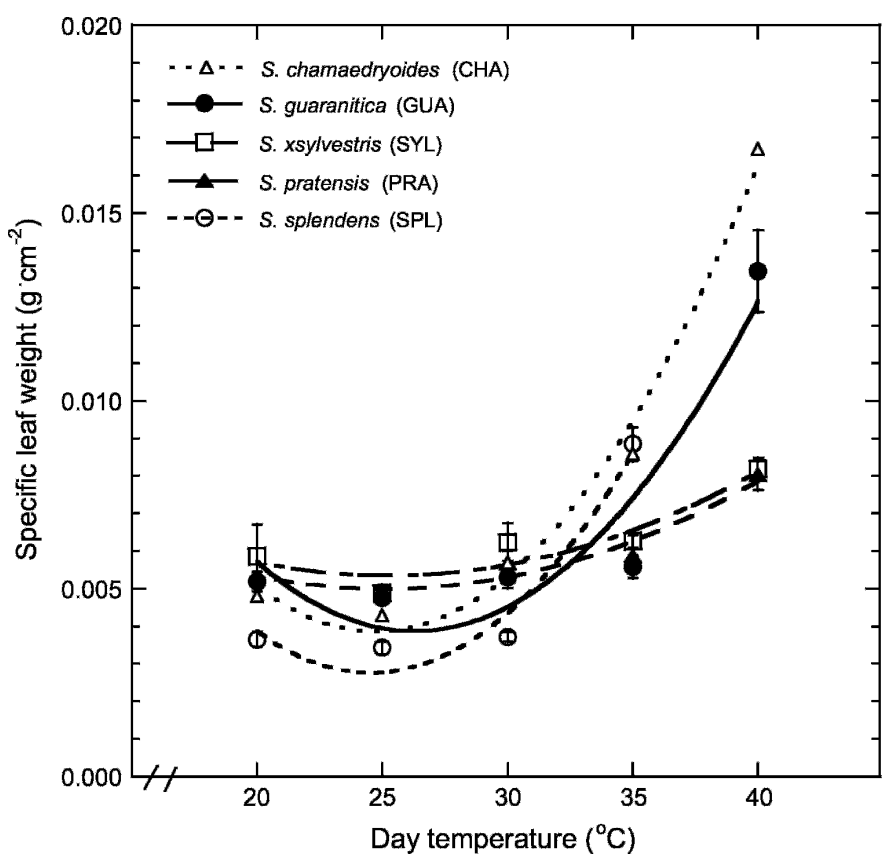

Fig. 5. Effects of day temperature on specific leaf weight of five Salvia taxa. Symbols are means of 16 observations, vertical bars are $\pm 1 \mathrm{SE}$, and curves show significant quadratic effects. S. chamaedryoides [CHA (specific leaf weight $\left.\left.=-2.2+0.39 \mathrm{x}-0.008 \mathrm{x}^{2}, R^{2}=0.92\right)\right], S$. guaranitica [GUA (specific leaf weight $\left.\left.=-9.58+1.83 \mathrm{x}-0.038 \mathrm{x}^{2}, R^{2}=0.99\right)\right], S . \times$ sylvestris 'Mainacht' [SYL (specific leaf weight $\left.\left.=-4.01+0.53 \mathrm{x}-0.007 \mathrm{x}^{2}, R^{2}=0.99\right)\right]$, S. pratensis [PRA (specific leaf weight $=-11.5+1.24 \mathrm{x}-0.019 \mathrm{x}^{2}, R^{2}=0.52$ )], and $S$. splendens [SPL (specific leaf weight $\left.\left.=-15.6+1.53 \mathrm{x}-0.030 \mathrm{x}^{2}, R^{2}=0.86\right)\right]$.

$\mathrm{P}_{\mathrm{n}}$ of LEU illustrated the high rate of productivity that this taxon is capable of under optimum conditions (days of $20^{\circ} \mathrm{C}$ ). However, growth of LEU at $20^{\circ} \mathrm{C}$ was dramatically reduced. Thus, high rates of $\mathrm{P}_{\mathrm{n}}$ do not necessarily translate into high rates of growth. Although temperature effects on $\mathrm{P}_{\mathrm{n}}$ provide a good indication how the physiological processes are affected by temperature, $\mathrm{P}_{\mathrm{n}}$ is not always a direct indicator of plant growth, because growth is affected by photosynthesis, respiration (not measured in this study), and leaf area characteristics.

Photosynthetic measurements indicated CHA, GRE, and GUA were more sensitive to high temperatures with plants either having negative or very low $\mathrm{P}_{\mathrm{n}}$ values at days of $40{ }^{\circ} \mathrm{C}$. This is supported by the precipitous decrease in top dry weight at $40{ }^{\circ} \mathrm{C}$ (Fig. 1). However, what is perhaps more interesting was the unchanging values for $\mathrm{P}_{n}$ at DT of 20,30 , or $40{ }^{\circ} \mathrm{C}$ in both SYL and PRA, two highly heat-tolerant taxa. Typically, increasing temperature 10 to $15{ }^{\circ} \mathrm{C}$ above normal growth temperature leads to disorganization of chloroplast thylakoid membranes, dissociation of photosystem II light-harvesting complex, destacking of grana lamellae, separation of nonbilayer lipids of thylakoid membranes, loss of photosynthetic $\mathrm{CO}_{2}$ evolution activity, denaturation and inactivation of many enzymes and thereby ultimately limiting photosynthesis (Dubey, 2005). The differential capacity to maintain $P_{n}$ at high temperatures indicated there is considerable variation in heat tolerance or ability to acclimate to elevated temperatures among Salvia species.

The $g_{\mathrm{s}}$ of all taxa was affected by DT with the exception of LEU (Table 3). Lower $g_{\text {s }}$ was evident at both the lowest $\left(20^{\circ} \mathrm{C}\right)$ and highest $\left(40^{\circ} \mathrm{C}\right)$ DTs for all taxa except LEU and SYL (at $25^{\circ} \mathrm{C} \mathrm{NT}$ only). Lower $g_{\mathrm{s}}$ at $20^{\circ} \mathrm{C}$ was likely related to low air temperature and decreased transpiration, whereas low $g_{\mathrm{s}}$ at $40{ }^{\circ} \mathrm{C}$ may have been indicative of stomatal closure. In many instances in which stomata tend to close with increasing temperature, the closure resulted from stomatal response to an increased vapor pressure deficit, which normally results when the air temperature is increased. The leaf-to-air vapor pressure difference at elevated leaf temperature has been shown to increase stomatal closure in SPL (Jiao and Grodzinski, 1996).

The increase in $g_{s}$ with increasing DT observed for SYL at NT of $25^{\circ} \mathrm{C}$ was unique among the taxa studied but has been reported for several other plants (Ranney and Peet, 1994). An increase in $g_{s}$ would typically result in increased transpiration and enhanced evaporative cooling, which could be an advantage at elevated temperatures (Burke and Upchurch, 1989) and would allow for greater $\mathrm{CO}_{2}$ uptake as long as water is not limiting.

Internal leaf $\mathrm{CO}_{2}$ concentration of GRE, GUA, and LEU increased from 30 to $40^{\circ} \mathrm{C}$, whereas $\mathrm{C}_{\mathrm{i}}$ of CHA, NEM, and SYL was significantly equivalent between 30 and $40{ }^{\circ} \mathrm{C}$ (data not presented). Thus, although $g_{\mathrm{s}}$ decreased from DTs of 30 to $40{ }^{\circ} \mathrm{C}$ except for SYL $\left(25^{\circ} \mathrm{C}\right.$ NT only), it appears that $\mathrm{P}_{\mathrm{n}}$ was not $\mathrm{CO}_{2}$-limited. In addition, $\mathrm{C}_{\mathrm{i}}$ at $40{ }^{\circ} \mathrm{C}$ was $287 \mathrm{mg} \cdot \mathrm{L}^{-1}$ or greater for all taxa, which should not be photosynthetically limiting for most $C_{3}$ plants (Sharkey, 1985). Increased $C_{i}$ most likely resulted from increased respiration rates and decreased $P_{n}$. These data indicated inhibition of $P_{n}$ at higher DTs was attributable largely to nonstomata limitations. This has been demonstrated in other herbaceous and woody perennial plants (Björkman et al., 1980; Ranney and Peet, 1994). Björkman et al. (1980) determined differences in $P_{n}$ response to high temperatures was attributed to differences in the thermal stability of chloroplast components, in particular the integrity of photosystem II. Variation in heat tolerance appeared to result from a variety of physiological factors that subsequently affected temperature optimum of $P_{n}$ and the capacity for maintaining $\mathrm{P}_{\mathrm{n}}$ at high DTs.

Maximum $\mathrm{P}_{\mathrm{n}}$ occurred at DTs of $20{ }^{\circ} \mathrm{C}$ for GRE and LEU and up to $40{ }^{\circ} \mathrm{C}$ in SYL and PRA (Table 3). Because the $900+$ species of Salvia span climates nearly worldwide ranging from cold temperate to tropical, the range of physiological responses should be expected to vary as observed in the present study. Of the three Old World taxa (NEM, SYL, and PRA), SYL and PRA showed no differences in $\mathrm{P}_{\mathrm{n}}$ from 20 to $40{ }^{\circ} \mathrm{C}$, although $g_{s}$ data indicated stomatal closure or partial closure of SYL was occurring at the higher DTs (at nights of $15^{\circ} \mathrm{C}$ only). In Europe, $S$. nemorosa (the wild-type equivalent of NEM) exhibited leaf temperatures ranging from $28{ }^{\circ} \mathrm{C}$ in near-pristine habitats to $37{ }^{\circ} \mathrm{C}$ in degraded habitats, yet $\mathrm{P}_{\mathrm{n}}$ did not differ between these extremes (Nagy et al., 1994). The heat tolerance observed in situ in $S$. nemorosa may help to explain results herein for both NEM and SYL. In addition, plants from habitats with large temperature variations during the growing season tend to possess a greater potential for acclimation over a wider temperature range than plants from habitats with relatively stable temperatures during the period of active growth (Berry and Björkman, 1980). Furthermore, ecological studies with Salvia apiana Jepson (california white sage), a desert species native to California, exhibited $\mathrm{P}_{\mathrm{n}}$ greater than $12 \mu \mathrm{mol} \cdot \mathrm{m}^{-2} \cdot \mathrm{s}^{-1}$ with a leaf temperature greater than $35^{\circ} \mathrm{C}$ (Schmitt et al., 1993) illustrating other Salvia have the capacity to maintain high $\mathrm{P}_{\mathrm{n}}$ at elevated temperatures.

Data herein provide a foundation for response of various Salvia taxa to day/night temperature in broader fashion than has 
Table 3. Photosynthesis and $g_{\mathrm{S}}$ of Salvia taxa grown under contrasting day/night temperature regimes.

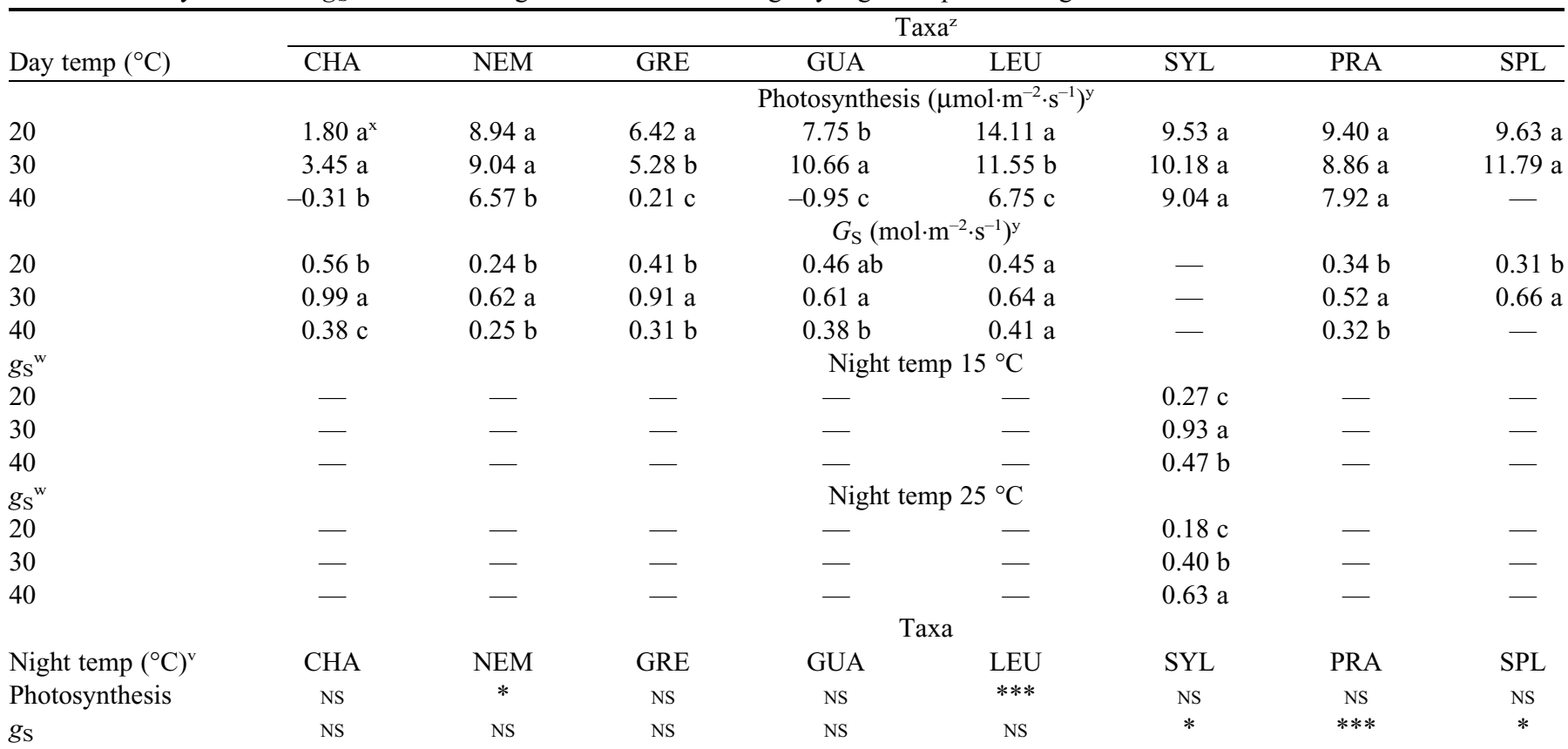

${ }^{\bar{z}}$ CHA, NEM, GRE, GUA, LEU, SYL, PRA, and SPL represent Salvia chamaedryoides, S. nemorosa Ostfriesland, S. greggii Furman's Red, S. guaranitica, S. leucantha, S. $\times$ sylvestris Mainacht, S. pratensis, and S. splendens, respectively.

yay temperature $\times$ night temperature interaction not significant.

${ }^{\times}$Mean separation within columns per factor or per night temperature by Fisher's protected least significant difference, $P=0.05$.

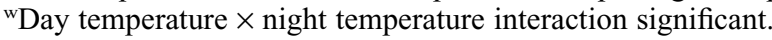

'Night temperature main effects analyzed separately.

Ns,*,**** Nonsignificant or significant at $P=0.05$ or 0.001 , respectively.

been reported previously. Responses of taxa of Old World origin versus those of New World origin were strikingly different. The three rosette-forming Old World taxa (NEM, SYL, and PRA) exhibited the greater tolerance to high DTs with the lowest relative reduction in growth and $\mathrm{P}_{\mathrm{n}}$ occurring at DTs $30{ }^{\circ} \mathrm{C}$ or greater compared with New World taxa. Results of this study demonstrate that much variation in heat tolerance exists in cultivated Salvia that may be exploited in selection and breeding programs.

\section{Literature Cited}

American Horticultural Society. 1997. The American Horticultural Society plant heat-zone map. Amer. Hort. Soc., Alexandria, VA.

Armitage, A.M. 1997. Herbaceous perennial plants: A treatise on their identification, culture, and garden attributes. 2nd ed. Stipes Publishing Co., Champaign, IL.

Armitage, A.M. and J.W. Billingsley. 1983. Influence of warm night temperatures on growth and flowering of Primula $\times$ polyanthus. HortScience 18:882-883.

Armitage, A.M. and J.M. Laushman. 1989. Photoperiodic control of flowering in Salvia leucantha. J. Amer. Soc. Hort. Sci. 114:755-758. Arnold, M.A. 1998. Size control and postproduction growth of container-grown perennial verbena, cherry sage, and lantana drenched with paclobutrazol. Plant Growth Regulat. Soc. Amer. Qrtly. 26:144-156.

Berry, J. and O. Bjökman. 1980. Photosynthetic response and adaptation to temperature in higher plants. Annu. Rev. Plant Physiol. 31:491-543.

Björkman, O., M.R. Dadger, and P.A. Armond. 1980. Response and adaptation to high temperatures, p. 233-239. In: Turner, N.C. and P.J. Kramer (eds.). Adaptation of plants to water and high temperature stress. Wiley, New York.
Burke, J.J. 1990. High temperature stress and adaptations in crops, p. 295-309. In: Alscher, R.G. and J.R. Cumming (eds.). Stress responses in plants: Adaptation and acclimation mechanisms. Wiley, New York.

Burke, J.J. 1995. Enzyme adaptation to temperature, p. 63-78. In: Smirnoff, N. (ed.). Environment and plant metabolism: Flexibility and acclimation. Bios Scientific Publ., Oxford, UK.

Burke, J.J. and D.R. Upchurch. 1989. Leaf temperature and transpirational control in cotton. Environ. Exp. Bot. 29:487-492.

Clebsch, B. 1997. A book of salvias: Sages for every garden. Timber Press, Portland, OR.

Compton, J. 1994. Mexican salvias in cultivation. The Plantsman 15:193-215.

Cooper, A.J. 1973. Root temperature and plant growth. Commonwealth Agr. Bur., Slough, UK.

Cooper, C.C. and D.P. Watson. 1954. Influence of root temperature and light intensity on flower bud development in Salvia splendens. Proc. Amer. Soc. Hort. Sci. 64:437-440.

Dubey, R.S. 2005. Photosynthesis in plants under stressful conditions, p. 717-734. In: Pessarakli, M. (ed.). Handbook of photosynthesis. 2nd ed. CRC Press, Boca Raton, FL.

Dweck, A.C. 2000. The folklore and cosmetic uses of various Salvia species, p. 1-25. In: Kintzios, S.E. (ed.). Sage: The genus Salvia. Harwood Acad. Publ., Amsterdam, The Netherlands.

Fitter, A.H. and R.K.M. Hay. 2002. Environmental physiology of plants. 3rd ed. Academic Press, San Diego.

Friend, A.L., M.D. Coleman, and J.G. Isebrands. 1994. Carbon allocation to root and shoot systems of woody plants, p. 245-273. In: David, T.D. and B.E. Haissig (eds.). Biology of adventitious root formation. Plenum Press, New York.

Harris, R.W., J.R. Clark, and N.P. Matheny. 1999. Arboriculture: Integrated management of landscape trees, shrubs, and vines. 3rd ed. Prentice-Hall, Upper Saddle River, NJ. 
Higuchi, H., W. Amaki, M. Minami, and S. Suzuki. 1987. Effects of high temperature on lateral shoot growth of salvia and impatiens after pruning. HortScience 22:618-619.

Hopkins, W.G. 1999. Introduction to plant physiology. 2nd ed. Wiley, New York.

Jiao, J. and B. Grodzinski. 1996. The effect of leaf temperature and photorespiratory conditions on export of sugars during steady state photosynthesis in Salvia splendens. Plant Physiol. 111:169-178.

Jull, L.G., T.G. Ranney, and F.A. Blazich. 1999. Heat tolerance of selected provenances of atlantic white cedar. J. Amer. Soc. Hort. Sci. 124:492-497.

Karlsson, M.G. 2002. Flower formation in Primula vulgaris is affected by temperature, photoperiod and daily light integral. Scientia Hort. 95:99-110.

Kasper, T.C. and W.L. Bland. 1992. Soil temperature and root growth. Soil Sci. 154:290-299.

Lambers, H., F.S. Chapin, III, and T.L. Pons. 1998. Plant physiological ecology. Springer-Verlag, New York.

Larcher, W. 1994. Photosynthesis as a tool for indicating temperature stress events, p. 261-277. In: Schulze, E.-D. and M.M. Caldwell (eds.). Ecophysiology of photosynthesis. Springer-Verlag, Berlin.

Latimer, J.G., P.A. Thomas, and P. Lewis. 1999. Plant growth regulator effects on height and landscape performance of perennial bedding plants. Acta Hort. 504:83-91.

Leegood, R.C. 1995. Effects of temperature on photosynthesis and photorespiration, p. 45-62. In: Smirnoff, N. (ed.). Environment and plant metabolism: Flexibility and acclimation. Bios Scientific Publ., Oxford, UK.

Levitt, J. 1980. Responses of plants to environmental stresses. 2nd. ed. Academic Press, New York.

Lord, T. (ed.). 2002. RHS plant finder 2002-2003. Dorling Kindersley, London.

Malek, A.A., F.A. Blazich, S.L. Warren, and J.E. Shelton. 1992. Initial growth of seedlings of mountain laurel as influenced by different day/ night temperatures. J. Amer. Soc. Hort. Sci. 117:736-739.

Matschat, C.H. 1935. Mexican plants for American gardens. Houghton Mifflin, Cambridge, MA.

McMichael, B.L. and J.J. Burke. 1998. Soil temperature and root growth. HortScience 33:947-951.

Nagy, Z., Z. Tuba, K. Szente, J. Uzvögyi, and G. Fekete. 1994. Photosynthesis and water use efficiency during degradation of a semiarid loess steppe. Photosynthetica 30:307-311.
Panagiotopoulos, E., C. Kapetanos, M. Skapeti, C. Cholevas, J. Drossopoulos, M. Loukas, and S.E. Kintzios. 2000. The ecophysiology of Salvia: Disorders and adaptation, p. 125-133. In: Kintzios, S.E. (ed.). Sage: The genus Salvia. Harwood Academic Publ., Amsterdam, The Netherlands.

Ranney, T.G., F.A. Blazich, and S.L. Warren. 1995. Heat tolerance of selected species and populations of rhododendron. J. Amer. Soc. Hort. Sci. 120:423-428.

Ranney, T.G. and M.M. Peet. 1994. Heat tolerance of five taxa of birch (Betula) physiological responses to supraoptimal leaf temperatures. J. Amer. Soc. Hort. Sci. 119:243-248.

Rowe, D.B., S.L. Warren, and F.A. Blazich. 1994. Seedling growth of catawba rhododendron. I. Temperature optima, leaf area, and dry weight distribution. HortScience 29:1298-1302.

Schmitt, A.K., C.E. Martin, V.S. Loeschen, and A. Schmitt. 1993. Mid-summer gas exchange and water relations of seven $C_{3}$ species in a desert wash in Baja California, Mexico. J. Arid Environ. 24:155164.

Sharkey, T.D. 1985. Photosynthesis in intact leaves of C3 plants. Physics, physiology and rate limitations. Bot. Rev. 51:53-105.

Sutton, J. 1999. The gardener's guide to growing salvias. Timber Press, Portland, OR.

Sytsma, K. and J.B. Walker. (site coords). 2003. Salvia research network: Molecular phylogenetics, evolution, and classification of Salvia and related Mentheae. 14 Dec. 2004. <www.botany.wisc.edu/ salvia/>.

Thomas, J.F., R.J. Downs, and C.H. Saravitz. 2004. Phytotron procedural manual for controlled environment research at the Southeastern Plant Environment Laboratory. North Carolina Agr. Res. Serv. Tech. Bul. 244 (revised). 10 Nov. 2004. <www.ncsu.edu/ phytotron/manual.pdf $>$.

van Iersel, M. 1997. Root restriction effects on growth and development of salvia (Salvia splendens). HortScience 32:1186-1190.

van Iersel, M.W. 2003. Short-term temperature change affects the carbon exchange characteristics and growth of four bedding plant species. J. Amer. Soc. Hort. Sci. 128:100-106.

Wilson, S.B., P.J. Stoffella, and D.A. Graetz. 2003. Compost amended media and irrigation system influence containerized perennial Salvia. J. Amer. Soc. Hort. Sci. 128:260-268.

Zimmer, K. 1980. Photoperiodische reaktion von Salvia splendens Sello: I. Einfluß der temperatur auf das wachstum unter kurztag- und langtagbedingungen. Gartenbauwissenschaft 45:129-132. 